Internal exposure to pollutants measured in blood and urine of Flemish adolescents in function of area of residence

Peer-reviewed author version

Schroijen, C.; Baeyens, W.; Schoeters, G.; Den Hond, E.; Koppen, G.; BRUCKERS, Liesbeth; Nelen, V.; De Mieroop, E. Van; Bilau, M.; Covaci, A.; Keune, H.; Loots, I.; KLEINJANS, J.; Dhooge, W. \& Van Larebeke, N. (2008) Internal exposure to pollutants measured in blood and urine of Flemish adolescents in function of area of residence. In: CHEMOSPHERE, 71(7). p. 1317-1325.

Handle: http://hdl.handle.net/1942/8272 


\title{
Internal exposure to pollutants measured in blood and urine of Flemish adolescents in function of area of residence
}

\author{
C. Schroijen ${ }^{\mathrm{a}, *}$, W. Baeyens ${ }^{\mathrm{a}}$, G. Schoeters ${ }^{\mathrm{b}}$, E. Den Hond ${ }^{\mathrm{b}}$, G. Koppen ${ }^{\mathrm{b}}$, L. Bruckers ${ }^{\mathrm{c}}$,

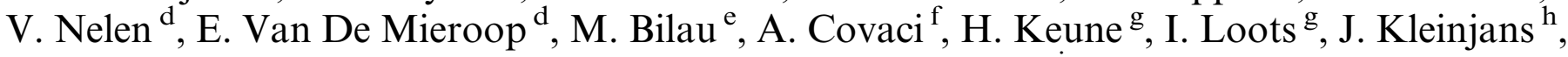 \\ W. Dhooge ${ }^{\mathrm{e}}, \mathrm{N}$. Van Larebeke ${ }^{\mathrm{i}}$ \\ ${ }^{a}$ Vrije Universiteit Brussel (VUB), Analytical and Environmental Chemistry (ANCH), Pleinlaan 2, 1050 Brussels, Belgium \\ ${ }^{\mathrm{b}}$ Flemish Institute of Technological Research (VITO), Boeretang 200, $2400 \mathrm{Mol}$, Belgium \\ ${ }^{\mathrm{c}}$ University of Hasselt, University Campus, Building D, 3590 Diepenbeek, Belgium \\ ${ }^{\mathrm{d}}$ Provincial Institute of Hygiene, Kronenburgstraat 45, 2000 Antwerp, Belgium \\ ${ }^{\mathrm{e}}$ Ghent University, Department of Public Health, De Pintelaan 185, 9000 Ghent, Belgium \\ ${ }^{\mathrm{f}}$ University of Antwerp (UA), Department of Pharmaceutical Science, Universiteitsplein 1, 2610 Wilrijk, Belgium \\ ${ }^{\mathrm{g}}$ University of Antwerp, Faculty of Political and Social Sciences, Sint Jacobstraat 2, 2000 Antwerp, Belgium \\ ${ }^{\mathrm{h}}$ Maastricht University, Department of Health, Risk Analysis and Toxicology, P.O. Box 616, 6200 MD Maastricht, The Netherlands \\ ${ }^{\mathrm{i}}$ Ghent University, Study Centre for Carcinogenesis and Primary Prevention of Cancer, Department of Radiotherapy and Nuclear Medicine, \\ De Pintelaan 185, 9000 Ghent, Belgium
}

Received 25 July 2007; received in revised form 13 November 2007; accepted 15 November 2007

Available online 24 January 2008

\begin{abstract}
The Centre for Environment and Health in Flanders, the Northern part of Belgium, started a biomonitoring program on adolescents in 2003. 1679 adolescents residing in nine areas with different patterns of pollution participated in the study. Possible confounding effects of lifestyle and personal characteristics were taken into account. The geometric mean levels of cadmium and lead in whole blood amounted to 0.36 and $21.7 \mu \mathrm{g}^{-1}$, those of PCBs, DDE and HCB in serum to 68, 94 and $20.9 \mathrm{ng} \mathrm{g}^{-1}$ fat, and those of 1 -hydroxypyrene and $t, t^{\prime}$-muconic acid in urine to $88 \mathrm{ng} \mathrm{g}^{-1}$ creatinine and $72 \mu \mathrm{g} \mathrm{g}^{-1}$ creatinine. Significant regional differences in internal lead, cadmium, PCBs, DDE and HCB exposure were observed in function of area of residence, even after adjustment for age, sex, smoking (and body mass index for the chlorinated compounds). Compared to a reference mean, internal exposure was significantly higher in one or more of the areas: $\mathrm{Cd}$ and $\mathrm{Pb}$ in the Antwerp agglomeration, $\mathrm{Cd}$ in the Antwerp harbour, PCBs in the Ghent agglomeration, PCBs, DDE and $\mathrm{HCB}$ in the Ghent harbour, Cd, PCBs, DDE and HCB in the rural area, DDE in Olen and in the Albert canal areas. Adolescents living in an area with intensive fruit cultivation (showing overall the lowest values) and, surprisingly, in areas around household waste incinerators (average of six areas), had no significantly increased internal exposures. Subjects from separate areas around waste incinerators showed significant differences in body load of various environmental contaminants.
\end{abstract}

(C) 2007 Elsevier Ltd. All rights reserved.

Keywords: Biomarkers; Heavy metals; Chlorinated compounds; Urinary metabolites; Health; Environment

\section{Introduction}

Flanders is one of the most populated areas in Europe, with a dense network of traffic roads, industrial activities

\footnotetext{
* Corresponding author. Tel.: +32 26293266; fax: +32 26293274 .

E-mail address: cschroij@vub.ac.be (C. Schroijen).
}

and intensive farming close to habitation. The Flemish Environment and Health Study (FLEHS) of 1999 provided evidence that levels of internal exposure to pollutants differed between a rural and an urban area. In addition, small differences in pollutant levels were associated with observable differences in effect biomarkers, such as mutation frequency, tumor markers, sexual development, etc. 
(Staessen et al., 2001; Koppen et al., 2002; Van den Heuvel et al., 2002; van Larebeke et al., 2006). The current results entailed a larger-scale, five year (2002-2006) biomonitoring program on neonates, adolescents and older adults carried out by the Flemish Centre for Environment and Health. The objectives were to measure and to compare internal exposure to pollutants in nine areas differing in pollution pressure and to assess whether observed differences in internal concentrations of pollutants were associated with biological and health effects. A maximum of relevant and useful knowledge resulting from this program as well as from existing knowledge will be put at the Flemish governments' disposal to support policy for better protection of humans' health and environment. All public information on the project can be found on the website www.milieuen-gezondheid.be.

Here we report on the internal exposure of 14 and 15 year old adolescents to environmental pollutants.

\section{Materials and methods}

\subsection{Selection of study areas}

Eight different study areas were selected on the basis of a characteristic, relevant and differing type of pollution pressure: the Antwerp agglomeration, the Ghent agglomeration, the aggregated industrial harbour areas of Antwerp and Ghent (mainly petrochemical and metallurgic industries, respectively), the industrial zone around the Albert canal (chemical industry), the industrial zone of Olen (non-ferrous industry), the immediate surroundings of household waste incinerators, a rural area with intensive fruit cultivation, and a rural area devoid of highways and of important local industrial emissions and with a population density of less than 250 inhabitants per $\mathrm{km}^{2}$. Initially, eight study areas were selected, but after statistical analyses of the results, the individual harbour areas of Antwerp and
Ghent seemed to be quite different and resembled more their adjacent urban area. The separation of the harbours resulted in nine areas instead of eight. The total surface of the studied area is $3036 \mathrm{~km}^{2}$, corresponding to $22 \%$ of the total surface of Flanders $\left(13521 \mathrm{~km}^{2}\right)$. The 65 selected municipalities correspond to $20 \%$ of the total Flemish municipalities. Except for 'rural Flanders' and for 'waste incinerators', all study areas are contiguous geographical entities. 'Rural Flanders' comprised 24 municipalities, spread out over 9 contiguous areas in the western half of Flanders. 'Waste incinerators' comprised 12 municipalities, spread out over the whole of Flanders. Fig. 1 shows the location of the nine areas of interest in Flanders.

\subsection{Selection and recruitment of participants}

In the selected areas approximately 1.2 million inhabitants are living which is $20 \%$ of the Flemish population. A sample size of 200 participants per study area was chosen because a power calculation demonstrated that this appears to be statistically sufficient to detect differences of $20 \%$ between study areas while the efficiency in estimation is the same for all study areas. As a consequence of the separation of the harbour areas, the sample size target of 200 was not met in the individual harbour areas of Antwerp $(n=76)$ and Ghent $(n=150)$. A stratified clustered multi-stage design was used to select 1600 participants as a random sample of the population under study. Sampling took place in three steps: first by study area, second by entities for access to participants, and third by selection of the participants in accordance with the inclusion criteria. The adolescents were enrolled via 50 schools located in the selected regions, and sampled between October 2003 and July 2004. Inclusion criteria were the following: being born in 1988 or 1989, studying in the third year of secondary school, living for at least five years in the same area, and giving informed consent (both adolescent

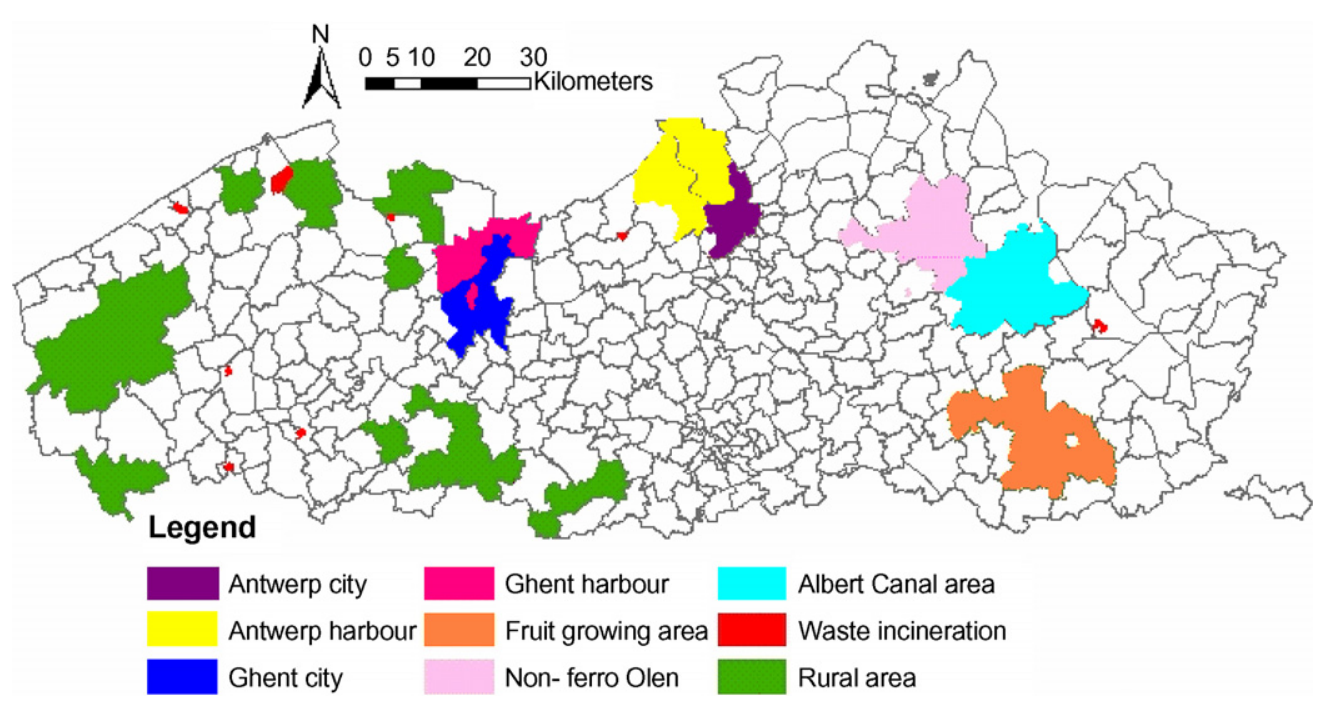

Fig. 1. Map of the nine areas of interest in which participants for the human biomonitoring program were recruited. 
and parents). Of all pupils who received the invitation $38.1 \%$ did not respond, and of those who responded $23.8 \%$ refused to participate, $8.2 \%$ did not fulfill the inclusion criteria, $3.5 \%$ were absent at the time of the examination, $1.4 \%$ had insufficient blood/urine samples or incomplete/no questionnaires and $1.3 \%$ were not included because the required number of participants was reached. For the areas around waste incinerators it was not possible to enroll adolescents through schools, because these areas comprised only a few streets. Therefore, adolescents living near an incinerator received a home-addressed letter for participation. The recruitment resulted in a total of 1679 adolescents.

\subsection{Blood and urine collection}

About $200 \mathrm{ml}$ of urine and $40 \mathrm{ml}$ of blood were sampled from each participant to carry out various analyses. The creatinine content in urine was determined spectrophotometrically by 'Algemeen Medisch Laboratorium' (AML) in Antwerp. $\mathrm{Na}_{2}$ EDTA $(10 \% \mathrm{v} / \mathrm{v})$ was added to whole blood while serum was prepared by immediate centrifugation of the coagulated blood. Samples were stored at $-20{ }^{\circ} \mathrm{C}$ until analysis. Length and body weight of the participants were also assessed at the same occasion of blood and urine collection.

\subsection{Information from questionnaires and data banks}

To obtain information on personal and lifestyle factors, participants were asked to fill out questionnaires. The parents of the participants completed a self-reporting questionnaire on their own education, weight, length and health status, on housing, residence history, family composition, social and financial situation, density of nearby traffic and in-house use of pesticides. The participating adolescents completed a self-reporting questionnaire on health status, exposure to traffic, in-house exposures to pollutants and chemicals, sports, hobbies, contact with pets, smoking and consumption of alcohol and drugs. They also completed two food frequency questionnaires in order to assess the daily consumption of fruit and vegetables on the one hand, and fat-containing food items on the other hand during the last year. In addition the consumption of locally produced food was recorded. The study design was approved by the medical-ethical committee of the University of Antwerp on 4th of July 2002.

\subsection{Chemical analysis of biomarkers of exposure}

The analysis entails measurements of biomarkers of exposure in the human body. Heavy metals (cadmium and lead) were determined in whole blood by the VUB. Cadmium levels in blood are generally regarded as a reflection of current exposure but cadmium levels in blood are also an estimate of the accumulated body burden of cadmium, many years after exposure (Wittman and Howard,
2002). Polychlorinated biphenyls (PCB 138, PCB 153 and PCB 180) and chlorinated pesticides ( $p, p^{\prime}$-dichlorodiphenyldichloroethylene (DDE) and hexachlorobenzene (HCB)) were analysed in serum by VITO and Toxicology Centre-UA. A general marker of PAH exposure (1-hydroxypyrene), and a marker of exposure to benzene ( $t, t^{\prime}$-muconic acid) were analysed in urine by VITO. All laboratories involved in the analyses of these biomarkers applied standard agreed quality control/quality assurance procedures.

\subsubsection{Analysis of heavy metals in whole blood}

Lead and cadmium concentrations in whole blood were determined after an acid digestion pre-treatment destroying the organic matrix followed by high resolution - inductively coupled plasma - mass spectrometry detection. Ultra clean material, pure reagents, clean room environment and very sensitive instrumentation were used to determine the low levels of cadmium and lead in whole blood. Briefly, $500 \mu 1$ whole blood, $500 \mu 1$ nitric acid and $100 \mu 1$ hydrogen peroxide were digested in closed vessels subjected to an increased pressure and temperature. The digested blood was diluted 10 times when analysed by the HR-ICP-MS. The detection limits for cadmium and lead in whole blood samples were 0.09 and $2.0 \mu \mathrm{g} 1^{-1}$, respectively.

\subsubsection{Analysis of PCBs and chlorinated pesticides in serum}

Serum PCBs (PCB 138, 153 and 180) and chlorinated pesticides (hexachlorobenzene and DDE, a metabolite of DDT) were analysed by two laboratories using two slightly different methods based on those described by Gomara et al. (2002) and Covaci and Schepens (2001). Summarized, blood serum was mixed with formic acid, internal standards were added, and the mixture was equilibrated in an ultrasonic bath. The sample was eluted through a solidphase extraction (SPE) cartridge. The SPE cartridge was washed, dried and placed on top of a multilayer column filled with anhydrous sodium sulphate and silica impignated with sulphuric acid. PCBs and chlorinated pesticides were eluted and concentrated. The extracts were analysed using gas chromatography combined with an electron capture detector. The detection limit of all chlorinated compounds in serum was $0.02 \mu \mathrm{g} 1^{-1}$.

\subsubsection{Analysis of a PAH and benzene metabolite in urine}

The methods used to determine 1-hydroxypyrene (a metabolite of pyrene) and $t, t^{\prime}$-muconic acid (a metabolite of benzene) in urine are based on those of Angerer and Schaller $(1997,1998)$. The determination of 1-hydroxypyrene was performed with high performance liquid chromatography (HPLC) with fluorescence detector. To release 1-hydroxypyrene from proteins, urine was hydrolysed by the enzymes $\beta$-glucuronidase and arylsulfatase during the night. Then 1-hydroxypyrene was on-line extracted from the urine matrix and enriched and separated on an apolar C-18 reversed phase column with a gradient solvent mix- 
ture of methanol and water. The detection limit was $0.060 \mu \mathrm{g} 1^{-1}$.

$t, t^{\prime}$-Muconic acid was determined in urine by means of ion chromatography using SPE-SAX columns. HPLC, with a solvent gradient of methanol and acetic acid $(1 \%$ $\mathrm{v} / \mathrm{v}$ ), was used to separate the extract from other compounds and quantification was done by a UV-detector. The detection limit was $8.6 \mu \mathrm{g}^{-1}$.

\subsection{Data treatment}

Database management and statistical analyses were performed with SAS for Windows, version 9.1.3 and Statistica, version 7.1. Data below the detection limit were set equal to half of the detection limit. Neperian logarithmic transformation of the exposure markers was performed because the data were not normally distributed. To assess differences in e.g., gender and smoking behaviour, a Student's $t$-test was applied. Differences in biomarkers of exposure between the nine areas, were initially investigated using analysis of variance (ANOVA). Subsequently, in regression analysis, raw data were adjusted for a number of confounders pre-specified based on literature data. The confounders included in the analysis were age, sex and smoking for all biomarkers of exposure and additionally body mass index (BMI) for the chlorinated compounds (PCBs, DDE and $\mathrm{HCB}$ ).

The mean and P90 biomarker values calculated from the pooled areas were defined as reference mean and reference P90 values. These reference values were weighted to inhabitant distribution, so the importance of each study area was proportional to the number of total inhabitants in that area. When the nine areas showed an overall significant difference in ANOVA, than the mean value of each study area was compared with the reference mean value and with the area showing the lowest mean value (Table 3); a statistical significance level of 5\% was used. Correlation between possible covariates and biomarker values was tested by stepwise multiple regression analysis in which the 5\% significance level was used for independent variables to enter and stay in the model. Confounders (age, sex, smoking and BMI for chlorinated compounds) were forced into the model. The squared semi-partial correlation coefficient was reported.

\section{Results}

\subsection{Short description of the study population}

The sampled group included 1679 adolescents, of which $53.1 \%$ males, with a mean age of 14.9 years (range: $13.8-$ 16.5). The mean body mass index of boys and girls was, respectively, 20.3 and $20.8 \mathrm{~kg} \mathrm{~m}^{-2}(p>0.05)$. In accordance with Flemish reference values of 'health behaviour in school-aged children', $13.6 \%$ of the adolescents smoked more than once a week and $14.2 \%$ used regularly alcohol. Statistical differences $(p<0.05)$ between the nine areas were observed in the use of locally produced food, exposure to traffic and education levels and incomes of the parents.

\subsection{Pollutants in blood, serum and urine: raw data}

A general observation was that inter-individual differences in biomarker levels per area are large and exceeding by far the differences in biomarker levels between the areas. However, for some of the biomarkers significant differences between inhabitants of specific areas can be observed. Table 1 summarizes the raw data concerning internal exposure for all areas. Overall significant differences $(p<0.0001)$ between areas were observed for lead, cadmium, PCBs, DDE and HCB. For these biomarkers, significant higher values were observed in inhabitants of most areas compared to the area with lowest value. People with lowest exposure pressure were living in the fruit area for lead and cadmium, in the region Olen for PCBs and $\mathrm{HCB}$, in the agglomeration of Antwerp for DDE and in the rural area for the PAH- and benzene-markers. Male adolescents had significant higher values than females for DDE (121 versus $92 \mathrm{ng} \mathrm{g}^{-1}$ fat, $p<0.0001$ ), HCB (22.8 versus $18.4 \mathrm{ng} \mathrm{g}^{-1}$ fat, $\left.p<0.0001\right)$, lead $\left(24.8 \mu \mathrm{g}^{-1}\right.$ versus $\left.18.1 \mu \mathrm{g} \mathrm{l^{-1 }}, p<0.0001\right)$ and PCBs (78 versus, $54 \mathrm{ng} \mathrm{g}^{-1}$ fat, $p<0.0001)$.

\subsection{Reference mean (RM) and reference P90: adjusted for personal or lifestyle factors}

Reference mean and P90 pollutant concentrations for the presence of pollutants in blood or urine of adolescents in Flanders were calculated after adjustment for the number of inhabitants in each of the areas and after adjustment for sex, age, and smoking behaviour. Additionally, chlorinated compounds were adjusted for body mass index (BMI). We consider this RM value as the average biomarker level in blood or urine of Flanders' adolescent (Table 2).

\subsection{Differences in internal exposure}

Levels of internal exposure after adjustment for confounders are shown in Table 3. Mean exposure values in a single area were compared to the RM values. For all biomarkers except 1-hydroxypyrene and t,t--muconic acid, significant differences were observed between the nine areas. Elevated exposure to PAHs and benzene was expected in the industrial zones in view of the reported emissions to air and surface water (Flemish Protection Agency, VMM). Differences remained significant after additional correction for socio-economic status through inclusion in ANOVA analysis of educational level of the parents and of income of the family (data not shown). In the Antwerp region (agglomeration and harbour) internal exposure to metals was significantly higher than the RM value, corresponding to high emissions by ferrous and 
Table 1

Raw data concerning internal exposure: median values (10th to 90th percentile)

\begin{tabular}{|c|c|c|c|c|c|c|c|}
\hline \multirow[t]{2}{*}{ Area } & \multicolumn{2}{|l|}{ Blood } & \multicolumn{3}{|l|}{ Serum } & \multicolumn{2}{|l|}{ Urine } \\
\hline & $\begin{array}{l}\text { Lead }^{\mathrm{a}} \\
\left(\mu \mathrm{g}^{-1}\right)^{* * * *}\end{array}$ & $\begin{array}{l}\text { Cadmiuma } \\
\left(\mu \mathrm{g}^{-1}\right)^{* * * *}\end{array}$ & $\begin{array}{l}\mathrm{PCBs}^{\mathrm{a}} \\
\left(\mathrm{ng} \mathrm{g}^{-1} \text { fat }\right)^{* * * *}\end{array}$ & $\begin{array}{l}\mathrm{DDE}^{\mathrm{a}} \\
\left(\mathrm{ng} \mathrm{g}^{-1} \text { fat }\right)^{* * * *}\end{array}$ & $\begin{array}{l}\mathrm{HCB}^{\mathrm{a}} \\
\left(\mathrm{ng} \mathrm{g}^{-1} \text { fat }\right)^{* * * *}\end{array}$ & $\begin{array}{l}\text { 1-OH-Pyrene } \\
\left(\mathrm{ng} \mathrm{g}^{-1}\right. \\
\text { creatinine) }\end{array}$ & $\begin{array}{l}t, t^{\prime} \text {-Muconic } \\
\text { acid }\left(\mu \mathrm{g} \mathrm{g}^{-1}\right. \\
\text { creatinine })\end{array}$ \\
\hline $\begin{array}{l}\text { Antwerp }^{\mathrm{b}} \\
\quad(n=210 ; \\
\left.\quad 81.0^{\mathrm{c}} ; 7.7 \% \mathrm{0}^{\mathrm{d}}\right)\end{array}$ & $\begin{array}{l}27.5^{* * * *} \\
(13.5-54.9)\end{array}$ & $\begin{array}{l}0.55^{* * * *} \\
(0.10-1.48)\end{array}$ & $\begin{array}{l}66 \\
(35-113)\end{array}$ & $\begin{array}{l}67 \\
(33-162)\end{array}$ & $\begin{array}{l}20.7^{* * * *} \\
(12.6-32.2)\end{array}$ & $\begin{array}{l}113 \\
(10-519)\end{array}$ & $\begin{array}{l}83 \\
(15-262)\end{array}$ \\
\hline $\begin{array}{l}\text { Antwerp } \\
\text { harbour }^{\mathrm{b}} \\
(n=76 ; \\
\left.80.3^{\mathrm{c}} ; 9.2^{\mathrm{o}}{ }^{\mathrm{d}}\right)\end{array}$ & $\begin{array}{l}27.6^{* * * *} \\
(10.7-55.3)\end{array}$ & $\begin{array}{l}0.60^{* * * *} \\
(0.19-1.15)\end{array}$ & $\begin{array}{l}67 \\
(32-111)\end{array}$ & $\begin{array}{l}82^{*} \\
(38-308)\end{array}$ & $\begin{array}{l}21.2^{* * *} \\
(13.0-30.5)\end{array}$ & $\begin{array}{l}127 \\
(13-708)\end{array}$ & $\begin{array}{l}86 \\
(10-279)\end{array}$ \\
\hline $\begin{array}{l}\text { Ghent } \mathrm{t}^{\mathrm{b}} \\
\qquad(n=207 ; \\
\left.\quad 76.3 \% 0^{\mathrm{c}} ; 1.4 \%{ }^{\mathrm{d}}\right)\end{array}$ & $\begin{array}{l}21.6^{* * * *} \\
(10.0-42.8)\end{array}$ & $\begin{array}{l}0.32^{* * * *} \\
(0.045-0.94)\end{array}$ & $\begin{array}{l}73^{* * * *} \\
(39-138)\end{array}$ & $\begin{array}{l}85^{* *} \\
(43-188)\end{array}$ & $\begin{array}{l}21.5^{* * * *} \\
(13.8-33.0)\end{array}$ & $\begin{array}{l}117 \\
(13-701)\end{array}$ & $\begin{array}{l}88 \\
(15-263)\end{array}$ \\
\hline $\begin{array}{l}\text { Ghent harbourb } \\
\quad(n=150 ; \\
\left.74.7 \%{ }^{\mathrm{c}} ; 13.3 \%{ }^{\mathrm{d}}\right)\end{array}$ & $\begin{array}{l}24.6^{* * * *} \\
(11.2-49.8)\end{array}$ & $\begin{array}{l}0.41^{* * * *} \\
(0.045-1.46)\end{array}$ & $\begin{array}{l}78^{* * * *} \\
(36-155)\end{array}$ & $\begin{array}{l}113^{* * * *} \\
(48-343)\end{array}$ & $\begin{array}{l}21.6^{* * * *} \\
(15.5-31.9)\end{array}$ & $\begin{array}{l}115 \\
(14-677)\end{array}$ & $\begin{array}{l}89 \\
(13-279)\end{array}$ \\
\hline $\begin{array}{l}\text { Fruit }^{\mathrm{b}} \\
\qquad(n=201 ; \\
\left.\quad 77.6 \% 0^{\mathrm{c}} ; 6.0 \% \mathrm{~d}^{\mathrm{d}}\right)\end{array}$ & $\begin{array}{l}15.9 \\
(6.9-34.6)\end{array}$ & $\begin{array}{l}0.16 \\
(0.045-0.79)\end{array}$ & $\begin{array}{l}59 \\
(36-113)\end{array}$ & $\begin{array}{l}88^{* * *} \\
(39-250)\end{array}$ & $\begin{array}{l}21.1^{* * * *} \\
(13.9-32.6)\end{array}$ & $\begin{array}{l}108 \\
(11-626)\end{array}$ & $\begin{array}{l}81 \\
(11-271)\end{array}$ \\
\hline $\begin{array}{l}\text { Rural }^{\mathrm{b}} \\
\quad(n=209 ; \\
\left.\quad 66.5^{\mathrm{c}} ; 4.8 \% \mathrm{~d}^{\mathrm{d}}\right)\end{array}$ & $\begin{array}{l}22.7^{* * * *} \\
(9.8-43.2)\end{array}$ & $\begin{array}{l}0.52^{* * * *} \\
(0.09-1.62)\end{array}$ & $\begin{array}{l}79^{* * * *} \\
(44-150)\end{array}$ & $\begin{array}{l}120^{* * * *} \\
(53-460)\end{array}$ & $\begin{array}{l}22.0^{* * * *} \\
(14.0-34.4)\end{array}$ & $\begin{array}{l}90 \\
(13-436)\end{array}$ & $\begin{array}{l}78 \\
(17-265)\end{array}$ \\
\hline $\begin{array}{l}\text { Olen }^{\mathrm{b}} \\
\quad(n=220 ; \\
\left.\quad 79.1 \%^{\mathrm{c}} ; 9.1 \%^{\mathrm{d}}\right)\end{array}$ & $\begin{array}{l}22.4^{* * * *} \\
(10.3-48.9)\end{array}$ & $\begin{array}{l}0.33^{* * * *} \\
(0.045-1.24)\end{array}$ & $\begin{array}{l}55 \\
(32-113)\end{array}$ & $\begin{array}{l}92^{* * * *} \\
(49-474)\end{array}$ & $\begin{array}{l}17.6 \\
(11.726 .6)\end{array}$ & $\begin{array}{l}136 \\
(14-794)\end{array}$ & $\begin{array}{l}92 \\
(10-247)\end{array}$ \\
\hline $\begin{array}{l}\text { Albert canal }^{\mathrm{b}} \\
\quad(n=199 ; \\
\left.\quad 79.9 \% 0^{\mathrm{c}} ; 16.2{ }^{\mathrm{d}}{ }^{\mathrm{d}}\right)\end{array}$ & $\begin{array}{l}18.6^{* *} \\
(8.8-43.0)\end{array}$ & $\begin{array}{l}0.39^{* * * *} \\
(0.09-1.30)\end{array}$ & $\begin{array}{l}59 \\
(30-112)\end{array}$ & $\begin{array}{l}146^{* * * *} \\
(59-592)\end{array}$ & $\begin{array}{l}20.3^{* * * *} \\
(13.5-32.9)\end{array}$ & $\begin{array}{l}108 \\
(14-778)\end{array}$ & $\begin{array}{l}87 \\
(12-290)\end{array}$ \\
\hline $\begin{array}{l}\text { Incineration }{ }^{\mathrm{b}} \\
\quad(n=207 ; \\
\left.\quad 80.2 \%{ }^{\mathrm{c}} ; 6.3 \%{ }^{\mathrm{d}}\right)\end{array}$ & $\begin{array}{l}21.1^{* * * *} \\
(10.3-40.7)\end{array}$ & $\begin{array}{l}0.42^{* * * *} \\
(0.045-1.10)\end{array}$ & $\begin{array}{l}66 \\
(33-116)\end{array}$ & $\begin{array}{l}84^{*} \\
(41-192)\end{array}$ & $\begin{array}{l}20.6^{* * * *} \\
(13.5-29.9)\end{array}$ & $\begin{array}{l}91 \\
(12-496)\end{array}$ & $\begin{array}{l}95 \\
(19-280)\end{array}$ \\
\hline $\begin{array}{l}\text { Total } \\
\qquad(n=1679 ; \\
\left.\quad 77.1 \%^{\mathrm{c}} ; 8.0^{\mathrm{o}} \mathrm{d}^{\mathrm{d}}\right)\end{array}$ & $\begin{array}{l}22.0 \\
(9.9-45.4)\end{array}$ & $\begin{array}{l}0.39 \\
(0.045-1.26)\end{array}$ & $\begin{array}{l}66 \\
(34-125)\end{array}$ & $\begin{array}{l}94 \\
(43-335)\end{array}$ & $\begin{array}{l}20.7 \\
(13.4-31.4)\end{array}$ & $\begin{array}{l}108 \\
(13-615)\end{array}$ & $\begin{array}{l}88 \\
(14-269)\end{array}$ \\
\hline
\end{tabular}

non-ferrous companies. In the Ghent region (agglomeration and harbour) this was the case for organochlorine compounds. No emission data are available for these compounds but PAH emissions are twice those in Antwerp harbour. A bit surprisingly, the rural area shows increased internal exposure levels for cadmium, PCBs, DDE and $\mathrm{HCB}$. A specific investigation to clarify these observations was launched in 2007. In the fruit area and, surprisingly, in the area composed of six surroundings of waste incinerators, no internal exposures were significantly increased compared to the RM value. For lead, cadmium, PCBs, DDE and $\mathrm{HCB}$, one or more of the nine areas had internal exposure values significantly below the RM. Compared to the area with the lowest internal exposure, significantly higher values were observed in the agglomeration of Antwerp for lead, cadmium, PCBs and HCB; in the Antwerp harbour area for lead, cadmium, DDE and $\mathrm{HCB}$; in the agglomeration of Ghent, the Ghent harbour area, the rural area and in the composed area around incin- erators for lead, cadmium, PCBs, DDE and HCB; in the fruit area for DDE and HCB; and in Olen for lead, cadmium, and DDE. Exposure levels in each harbour area were more similar to those of the adjacent agglomeration than to those of the other harbour area. Overall, the lowest internal exposures values were observed in the fruit area. In Table 3 an exclamation mark indicates those areas with P90 values that are significantly above the reference P90 value. Increased P90 values were always associated with increased mean values.

\subsection{Individual waste incinerators show differences in exposure}

The mean biomarker values of the area composed of six areas around waste incinerators were not significantly different from the RM values. However, if the six areas were considered individually, some of them had significant higher internal exposure values (after adjustment for 
Table 2

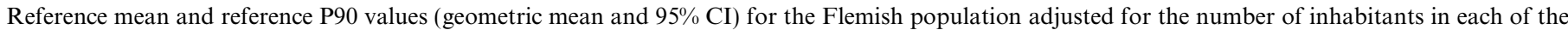
areas included in the study

\begin{tabular}{|c|c|c|c|c|}
\hline \multirow{2}{*}{$\begin{array}{l}\text { Age group } \rightarrow \\
\text { Biomarker of exposure } \downarrow\end{array}$} & \multicolumn{2}{|c|}{ Adolescents (14-15 yr) } & \multirow{2}{*}{$\begin{array}{l}\text { Neonates } \\
\text { Reference mean }\end{array}$} & \multirow{2}{*}{$\begin{array}{l}\text { Adults }(50-65 \mathrm{yr}) \\
\text { Reference mean }\end{array}$} \\
\hline & Reference mean & Reference P90 & & \\
\hline Lead $\left(\mu \mathrm{g} \mathrm{l}^{-1}\right)$ & $21.7(20.8-22.6)$ & $47(44-49)$ & $14.7(14.0-15.5)$ & $39.6(38.4-40.9)$ \\
\hline Cadmium $\left(\mu \mathrm{g} \mathrm{l}^{-1}\right)$ & $0.36(0.33-0.38)$ & $1.32(1.23-1.40)$ & $0.21(0.19-0.23)$ & $0.42(0.40-0.44)$ \\
\hline PCBs (ng $g^{-1}$ fat) & $68(66-70)$ & $116(111-121)$ & $64(61-68)$ & $333(325-341)$ \\
\hline DDE (ng g ${ }^{-1}$ fat) & 94 (89-99) & $274(242-306)$ & $110(104-116)$ & $423(398-449)$ \\
\hline $\mathrm{HCB}\left(\mathrm{ng} \mathrm{g}^{-1}\right.$ fat $)$ & $21(20-21)$ & $31(29-32)$ & $19(18-20)$ & $57(55-59)$ \\
\hline 1-Hydroxypyrene ( $\mathrm{ng} \mathrm{g}^{-1}$ creatinine) & $88(81-95)$ & $484(409-559)$ & / & $147(138-157)$ \\
\hline$t, t^{\prime}$-Muconic acid ( $\mu \mathrm{g} \mathrm{g}^{-1}$ creatinine) & $72(66-79)$ & $271(241-300)$ & / & $85(79-92)$ \\
\hline
\end{tabular}

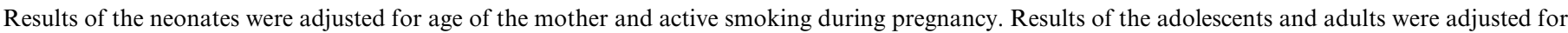
sex, age, smoking behaviour for all markers and also for body mass index for chlorinated compounds.

Table 3

Geometric means and $95 \%$ confidence interval of internal exposure to environmental pollutants in nine areas

\begin{tabular}{|c|c|c|c|c|c|c|c|}
\hline \multirow[t]{2}{*}{ Area } & \multicolumn{2}{|c|}{ Blood } & \multicolumn{3}{|c|}{ Serum } & \multicolumn{2}{|c|}{ Urine } \\
\hline & $\begin{array}{l}\text { Lead }^{\mathrm{a}} \\
\left(\mu \mathrm{g} \mathrm{l}^{-1}\right) * * * *\end{array}$ & $\begin{array}{l}\text { Cadmium }^{\mathbf{a}} \\
\left(\mu \mathrm{g} \mathrm{l}^{-1}\right) * * * *\end{array}$ & $\begin{array}{l}\mathbf{P C B s}^{\mathbf{a}} \\
\left(\mathrm{ng} \mathrm{g}^{-1} \text { fat }\right) * * * *\end{array}$ & $\begin{array}{l}\mathbf{D D E}^{\mathbf{a}} \\
\left(\mathrm{ng} \mathrm{g}^{-1} \text { fat }\right) * * * *\end{array}$ & $\begin{array}{l}\mathbf{H C B}^{\mathbf{a}} \\
\left(\mathrm{ng} \mathrm{g}^{-1} \text { fat }\right) * * * *\end{array}$ & $\begin{array}{l}\text { 1-OH-pyrene } \\
\text { (ng g }{ }^{-1} \text { creatinine) }\end{array}$ & $\begin{array}{l}\text { t,t'-muconic acid } \\
\left(\mu \mathrm{g} \mathrm{g}^{-1} \text { creatinine }\right)\end{array}$ \\
\hline $\begin{array}{l}\text { Antwerpb }^{\mathbf{b}} \\
(\mathrm{n}=210)\end{array}$ & $\begin{array}{l}25.1 * * * * \\
(23.1-27.3)\end{array}$ & $\begin{array}{l}0.47 * * * * \quad ! \\
(0.40-0.54)\end{array}$ & $\begin{array}{l}61 * \\
(57-64)\end{array}$ & $\begin{array}{l}73 \\
(65-82)\end{array}$ & $\begin{array}{l}19.9 * * * * \\
(19.1-20.8)\end{array}$ & $\begin{array}{l}95 \\
(78-116)\end{array}$ & $\begin{array}{l}72 \\
(60-200)\end{array}$ \\
\hline $\begin{array}{l}\text { Antwerp } \\
\text { Harbour }^{\mathbf{b}} \\
(\mathrm{n}=76)\end{array}$ & $\begin{array}{l}23.2 * * * * \\
(20.3-26.4)\end{array}$ & $\begin{array}{l}0.48 * * * * \\
(0.38-0.61)\end{array}$ & $\begin{array}{l}61 \\
(55-67)\end{array}$ & $\begin{array}{l}87 * \\
(73-103)\end{array}$ & $\begin{array}{l}20.0 * * * \\
(18.7-21.5)\end{array}$ & $\begin{array}{l}122 \\
(88-169)\end{array}$ & $\begin{array}{l}68 \\
(50-68)\end{array}$ \\
\hline $\begin{array}{l}\text { Ghent }^{\mathbf{b}} \\
(\mathrm{n}=207)\end{array}$ & $\begin{array}{l}21.0 * * * * \\
(19.4-22.8)\end{array}$ & $\begin{array}{l}0.30 * * * * \\
(0.26-0.34)\end{array}$ & $\begin{array}{l}74 * * * * \quad ! \\
(70-79)\end{array}$ & $\begin{array}{l}87 * * \\
(78-97)\end{array}$ & $\begin{array}{l}21.0 * * * * \\
(20.1-22.0)\end{array}$ & $\begin{array}{l}116 \\
(96-141)\end{array}$ & $\begin{array}{l}72 \\
(61-200)\end{array}$ \\
\hline $\begin{array}{l}\text { Ghent } \\
\text { harbour }^{b} \\
(n=150)\end{array}$ & $\begin{array}{l}23.4 * * * * \\
(21.3-25.7)\end{array}$ & $\begin{array}{l}0.33 * * * * \\
(0.28-0.39)\end{array}$ & $\begin{array}{l}76.3^{* * * * *} ! \\
(71.3-82)\end{array}$ & $\begin{array}{l}125 * * * * ! \\
(110-141)\end{array}$ & $\begin{array}{l}22.1 * * * * \\
(21.1-23.2)\end{array}$ & $\begin{array}{l}106 \\
(84-134)\end{array}$ & $\begin{array}{l}70 \\
(57-134)\end{array}$ \\
\hline $\begin{array}{l}\text { Fruit }^{\mathbf{b}} \\
(n=201)\end{array}$ & $\begin{array}{l}15.4 \\
(14.2-16.8)\end{array}$ & $\begin{array}{l}0.16 \\
(0.14-0.19)\end{array}$ & $\begin{array}{l}61 \\
(58-65)\end{array}$ & $\begin{array}{l}95 * * * \\
(85-106)\end{array}$ & $\begin{array}{l}21.5 * * * * \\
(20.6-22.5)\end{array}$ & $\begin{array}{l}98 \\
(81-118)\end{array}$ & $\begin{array}{l}71 \\
(60-199)\end{array}$ \\
\hline $\begin{array}{l}\text { Rural }^{\mathbf{b}} \\
(\mathrm{n}=209)\end{array}$ & $\begin{array}{l}21.8 * * * * \\
(20.1-23.6)\end{array}$ & $\begin{array}{l}0.46 * * * * \quad ! \\
(0.40-0.53)\end{array}$ & $\begin{array}{l}78 * * * * ! \\
(74-83)\end{array}$ & $\begin{array}{l}140 * * * * \quad ! \\
(126-156)\end{array}$ & $\begin{array}{l}22.0 * * * * \quad ! \\
(21.1-23.0)\end{array}$ & $\begin{array}{l}89 \\
(74-108)\end{array}$ & $\begin{array}{l}73 \\
(61-197)\end{array}$ \\
\hline $\begin{array}{l}\text { Olen }^{\mathbf{b}} \\
(n=220)\end{array}$ & $\begin{array}{l}22.6 * * * * \\
(20.9-24.4)\end{array}$ & $\begin{array}{l}0.32 * * * * \\
(0.28-0.37)\end{array}$ & $\begin{array}{l}58 \\
(55-62)\end{array}$ & $\begin{array}{l}117 * * * * ! \\
(106-130)\end{array}$ & $\begin{array}{l}17.6 \\
(16.9-18.4)\end{array}$ & $\begin{array}{l}115 \\
(95-139)\end{array}$ & $\begin{array}{l}73 \\
(62-199)\end{array}$ \\
\hline $\begin{array}{l}\text { Albert canal }^{\mathbf{b}} \\
(\mathrm{n}=199)\end{array}$ & $\begin{array}{l}17.5 * * * * \\
(16.1-19.0)\end{array}$ & $\begin{array}{l}0.36 * * * * \\
(0.31-0.41)\end{array}$ & $\begin{array}{l}57 \\
(54-60)\end{array}$ & $\begin{array}{l}166 * * * * \quad ! \\
(148-185)\end{array}$ & $\begin{array}{l}20.4 * * * * \\
(19.6-21.3)\end{array}$ & $\begin{array}{l}104 \\
(86-127)\end{array}$ & $\begin{array}{l}76 \\
(63-198)\end{array}$ \\
\hline $\begin{array}{l}\text { Incineration }^{\mathbf{b}} \\
(\mathrm{n}=207)\end{array}$ & $\begin{array}{l}21.6 * * * * \\
(19.9-23.5)\end{array}$ & $\begin{array}{l}0.36 * * * * \\
(0.31-0.41)\end{array}$ & $\begin{array}{l}62 * \\
(58-66)\end{array}$ & $\begin{array}{l}87 * * \\
(78-97)\end{array}$ & $\begin{array}{l}19.9 * * * * \\
(19.1-20.8)\end{array}$ & $\begin{array}{l}96 \\
(79-117)\end{array}$ & $\begin{array}{l}76 \\
(63-200)\end{array}$ \\
\hline
\end{tabular}

All biomarker results are adjusted for age, sex and smoking, and the chlorinated compounds (PCB, DDE and HCB) also for body mass index. Significantly lower and higher results compared to the reference mean are indicated in light grey and dark grey, respectively.

confounders) compared to the RM and differences among the areas showed up as well (Table 4). Adolescents living in the neighbourhood of the incinerator of Wilrijk had significant higher lead concentrations in their blood and those of Harelbeke showed higher cadmium levels. Mean levels of PCBs and HCB were highest in blood samples of adoles- cents from Menen. The mean values of DDE and cadmium were also high in Menen, but due to the small population group (large confidence intervals) the significance level was not reached. The benzene-marker $t, t^{\prime}$-muconic acid was significantly increased in urine samples of adolescents living nearby the incinerator of Roeselare. 
Table 4

Geometric means of internal exposure to environmental pollutants in the neighbourhood of six incinerators

\begin{tabular}{|c|c|c|c|c|c|c|c|}
\hline \multirow[t]{2}{*}{ Area } & \multicolumn{2}{|c|}{ Blood } & \multicolumn{3}{|c|}{ Serum } & \multicolumn{2}{|c|}{ Urine } \\
\hline & $\begin{array}{c}\text { Lead } \\
\left(\mu \mathrm{g} \mathrm{l}^{-1}\right)\end{array}$ & $\begin{array}{l}\text { Cadmium } \\
\qquad\left(\mu \mathrm{g} \mathrm{l}^{-1}\right)\end{array}$ & $\begin{array}{c}\text { PCBs } \\
\left(\text { ng g }^{-1} \text { fat }\right)\end{array}$ & $\begin{array}{c}\text { DDE } \\
\left(\mathrm{ng} \mathrm{g}^{-1} \text { fat }\right)\end{array}$ & $\begin{array}{c}\text { HCB } \\
\left(\text { ng g }^{-1} \text { fat }\right)\end{array}$ & $\begin{array}{c}\text { 1-OH-pyrene } \\
\text { (ng g }{ }^{-1} \text { creatinine) }\end{array}$ & $\begin{array}{l}\text { t,t'-muconic acid } \\
\left(\mu \mathrm{g} \mathrm{g}^{-1} \text { creatinine }\right)\end{array}$ \\
\hline Menen ( $n=14)$ & 18.2 & 0.56 & 114 & 117 & 28.2 & 68 & 98 \\
\hline Harelbeke (n=26) & 19.9 & 0.54 & 75 & 109 & 22.2 & 72 & 61 \\
\hline Roeselare (n=24) & 20.4 & 0.31 & 67 & 63 & 18.8 & 64 & 210 \\
\hline Ghent $(n=30)$ & 18.2 & 0.12 & 73 & 72 & 20.5 & 115 & 59 \\
\hline Wilrijk (n=72) & 27.2 & 0.36 & 60 & 73 & 18.5 & 81 & 78 \\
\hline Houthalen $(n=46)$ & 18.1 & 0.40 & 51 & 114 & 20.5 & 103 & 57 \\
\hline $\begin{array}{l}\text { Difference between } \\
\text { incinerators } \\
\text { (p-value) }\end{array}$ & 0.011 & $<0.0001$ & $<0.0001$ & 0.0006 & $<0.0001$ & 0.1 & 0.0014 \\
\hline
\end{tabular}

All biomarker results are adjusted for age, sex and smoking, and the chlorinated compounds (PCB, DDE and HCB) also for body mass index. Significant lower and higher results compared to the reference mean are indicated in light grey and dark grey, respectively.

\subsection{Factors explaining differences in levels of internal exposure}

Fig. 2 shows the significant factors explaining part of the variation in internal exposure among the adolescents. Area of residence and sex were important factors for almost all biomarkers. Boys had higher concentrations of pollutants in their body as compared to girls. Smoking was associated with higher levels of cadmium and 1-hydroxypyrene. Consumption of locally produced food was associated with higher concentrations of persistent chlorinated compounds in serum. The latter compounds were also increased in adolescents who had received breast-feeding as newborns: breastfed and non-breastfed adolescents had PCB concentrations of 74.0 and $55.2 \mathrm{ng} \mathrm{g}^{-1}$ fat, respectively.

\section{Discussion}

Our biomonitoring program showed small differences in internal exposure levels of adolescents living in nine selected areas. Compared to German Surveys on pupils, we obtained similar results for lead, $\mathrm{HCB}$ and DDE, although levels of the later compound were very variable according the geographical area. Our cadmium levels were somewhat increased, our PCB values decreased (Wilhelm et al., 2003, 2006). CDC reported mostly lower values, except for DDE (CDC, 2005).

Compared to the 17 year-old adolescents studied in the 1999 Flemish environment and health study (Staessen et al., 2001), no marked differences were observed in the current study group of 14 year old adolescents, for lead (19.2 versus $\left.21.7 \mu \mathrm{g}^{-1}\right)$ and cadmium (0.37 versus $0.36 \mu \mathrm{g}^{-1}$ ). Significant differences were observed for the marker PCBs (93 versus $68 \mathrm{ng} \mathrm{g}^{-1}$ fat), 1-hydroxypyrene
(68 versus $88 \mathrm{ng} \mathrm{g}^{-1}$ creatinine) and for $t, t^{\prime}$-muconic acid (55 versus $72 \mu \mathrm{g} \mathrm{g}^{-1}$ creatinine).

During our first biomonitoring campaign (2002-2003) on neonates and their mothers, lower lead and cadmium levels were found in cord blood, whereas levels of PCBs, DDE and HCB were quite similar (Table 2). Differences in transport through the placenta are suggested. In our third biomonitoring campaign (2004-2005) on 50-65 year old adults, all internal exposure levels were higher (Table 2) which might be a consequence of life-time exposure.

Significant differences in internal exposure between adolescents residing in different areas were noted for lead, cadmium, PCBs, HCB and DDE. In Flanders, a densely populated and heavily industrialized region, residents of areas with a surface of the order of 100 to several hundreds of square kilometers that harbour quite different economic activities show quite similar levels of internal exposure to pollutants. For Antwerp and Ghent there was no significant difference between the inner-city and the adjacent harbour and incinerator. Somewhat contrasting with this finding is the fact that residents of small areas, with a surface of less than $10 \mathrm{~km}^{2}$ around a point source (e.g., a household waste incinerator), may show significant increases in internal exposure compared to other areas and to the reference value.

Large inter-individual differences between adolescents residing in the same area were noted for all pollutants. As to factors underlying differences in internal exposure to pollutants, recorded distinctions in food consumption, exposure to traffic or other lifestyle or personal factors could only explain these differences to a limited extent. Indeed, for lead only $13.4 \%$ of variation could be explained by factors significantly associated with this parameter, for cadmium $14.4 \%$, for PCBs $46.6 \%$, for DDE $19.1 \%$, for $\mathrm{HCB}$ $28.5 \%$, for $t, t^{\prime}$-muconic acid $2.0 \%$, and for 1-hydroxypyrene 

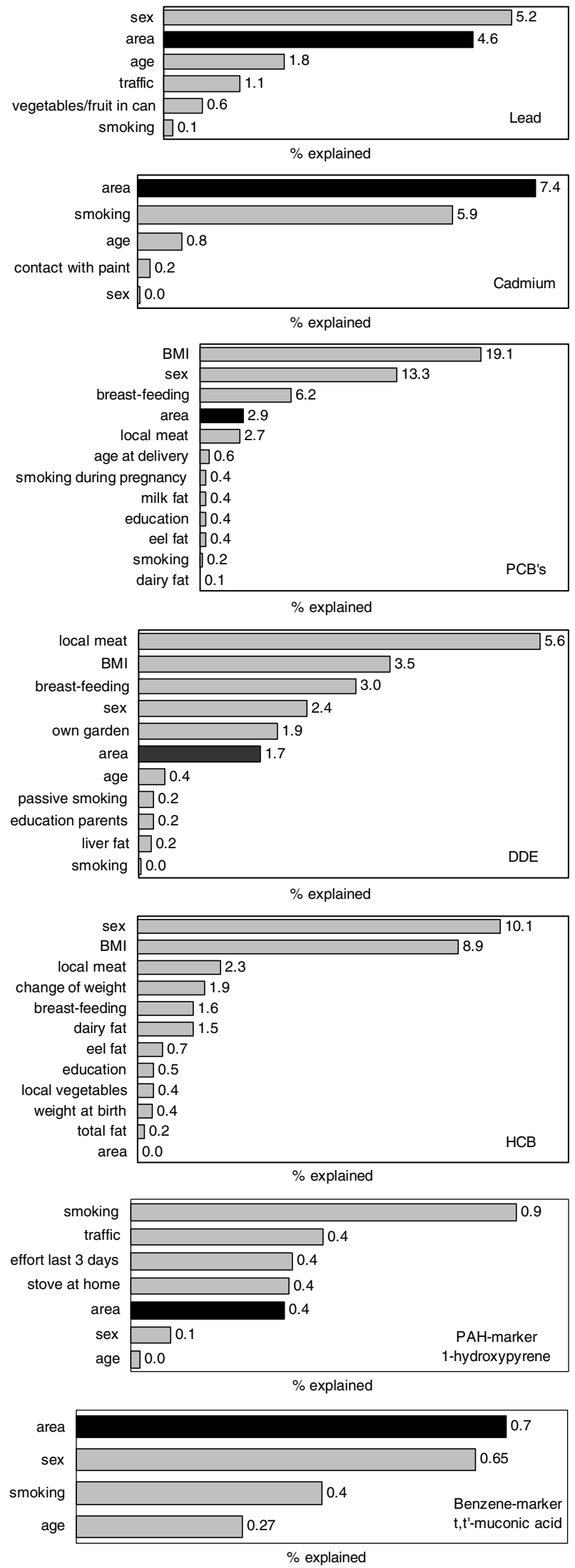

Fig. 2. Relative importance (squared semi-partial correlation coefficients in stepwise multiple regression analyses) of a series of variables explaining the differences in internal exposure. Area of residence is marked darker.
$2.5 \%$. For lead and cadmium levels, for $t, t^{\prime}$-muconic acid and to a lesser extent for PCBs, DDE and 1-hydroxypyrene, area of residence was one of the factors showing the strongest correlation with the parameter of internal exposure. As expected, BMI and having received breast-feeding were quite strongly and positively correlated with concentrations of PCBs, DDE and HCB. Overall, boys had higher concentrations of pollutants in blood. Smoking increased the internal exposure to cadmium and PAHs. The influence of breast feeding, gender and smoking were in agreement with other studies (Staessen et al., 2001; De Burbure et al., 2003; Strömberg et al., 2003; Wilhelm et al., 2003; Wilhelm et al., 2006). Exposure to traffic, having exercised in the last three days and having a stove at home were associated with higher internal exposure to PAHs. Interestingly, consumption of locally produced food items was positively correlated with concentrations of PCBs, DDE and $\mathrm{HCB}$, suggesting higher pollutant burdens in such food. It is known that fat intake is to a large extent responsible for contamination with persistent lipophilic pollutants (Fries, 1995 ) and that vegetable food is an important factor in contamination with heavy metals (Muñoz et al., 2005). The variation in age between adolescents in this study was too small to have a significant effect of age on the internal exposure levels as seen in some other studies.

\section{Conclusion}

Nine areas in Flanders, each representing a specific environmental stress (e.g., metals or organochlorides in industrial areas, pesticides in fruit area, etc.) were selected. Although Flanders is a densely populated region, with people consuming the same food distributed through the same chains of shops and submitted to similar pollution from traffic, etc. differences between areas were relatively small. There was for example no significant difference in exposure to pollutants between the inner-city, the adjacent harbour and incinerator, all located in the same agglomeration (e.g., Antwerp and Ghent). Nevertheless, some point sources such as the individual waste incinerators, caused significant differences in internal exposure. In addition, small differences were observed between some of the nine areas. Inhabitants of the agglomeration of Antwerp had higher exposure to heavy metals but lower exposure to halogenated compounds compared to the reference value. The halogenated compounds were significantly higher in the harbour of Ghent and in the rural area. The fruit area had in general low exposure to all measured pollutants. Additionally, elevated levels of DDE were mainly found in Olen and the Albert canal zone. The results of this study are in line with results from earlier biomonitoring studies in Flanders and from similar industrialized countries.

\section{Acknowledgements}

The study was commissioned, financed and steered by the Ministry of the Flemish Community (Department of 
Economics, Science and Innovation; Flemish Agency for Care and Health; and Department of Environment, Nature and Energy). The work was performed by The Flemish Centre of expertise for Environment and Health. We gratefully acknowledge the collaboration of the 42 Flemish schools, the (psycho-medical) centres for guidance of pupils, all participating adolescents and their parents.

\section{References}

Angerer, J., Schaller, K.H., 1997. In: Analyses of Hazardous Substances in Biological Materials, vol. 5. Wiley-VCH, pp. 125-141.

Angerer, J., Schaller, K.H., 1998. In: Analyses of Hazardous Substances in Biological Materials, vol. 6. Wiley-VCH, pp. 170-187.

Centers for Disease Control and Prevention (CDC), 2005. Third National Report on Human Exposure to Environmental Chemicals. National Center for Environmental Health Pub. No. 05-0570.

Covaci, A., Schepens, P., 2001. Improved determination of selected POPs in human serum by solid phase disk extraction and GC-MS. Chemosphere 43, 439-447.

De Burbure, C., Buchet, J.P., Bernard, A., Leroyer, A., Nisse, C., Haguenoer, J.M., Bergamaschi, E., Mutti, A., 2003. Biomarkers of renal effects in children and adults with low environmental exposure to heavy metals. J. Toxicol. Environ. Health A 66, 783-798 (current issues).

Fries, G., 1995. Review of the significance of animal food products as potential pathways of human exposures to dioxins. J. Anim. Sci. 73, $1639-1650$.

Gomara, B., Ramos, L., Gonzalez, M.J., 2002. Determination of polychlorinated biphenyls in small-size serum samples by solid-phase extraction followed by gas chromatography with micro-electroncapture detection. J. Chromatogr., B 766, 279-287.

Koppen, G., Covaci, A., Van Cleuvenbergen, R., Schepens, P., Winneke, G., Nelen, V., van Larebeke, N., Vlietinck, R., Schoeters, G., 2002. Persistent organochlorine pollutants in human serum of 50-65 years old women in the flanders environmental and health study (FLESH).
Part 1: concentrations and regional differences. Chemosphere 48, 811825.

Muñoz, O., Bastias, J.M., Araya, M., Morales, A., Orellana, C., Rebolledo, R., Velez, D., 2005. Estimation of the dietary intake of cadmium, lead, mercury, and arsenic by the population of Santiago (Chile) using a total diet study. Food Chem. Toxicol. 43, 1647-1655.

Staessen, J., Nawrot, T., Den Hond, E., Thijs, L., Fagard, R., Hoppenbrouwers, K., Koppen, G., Nelen, V., Schoeters, G., Vanderschueren, D., Van Hecke, E., Verschaeve, L., Vlietinck, R., Roels, H., 2001. Renal function, cytogenetic measurements, and sexual development in adolescents in relation to environmental pollutants: a feasibility study of biomarkers. Lancet 357, 1660-1669.

Strömberg, U., Lundh, T., Schütz, A., Skerfving, S., 2003. Yearly measurements of blood lead in Swedish children since 1978: an update focusing on the petrol lead free period 1995-2001. Occup. Environ. Med. 60, 370-372.

Van den Heuvel, R., Koppen, G., Staessen, J., Den hond, E., Verheyen, G., Nawrot, T., Roels, H., Vlietinck, R., Schoeters, G., 2002. Immunologic biomarkers in relation to exposure markers of PCBs and dioxins in Flemish adolescents (Belgium). Environ. Health Persp. 110, 595-600.

van Larebeke, N., Bracke, M., Nelen, V., Koppen, G., Schoeters, G., Van Loon, H., Vlietinck, R., 2006. Differences in tumor-associated protein levels among middle-age Flemish women in association with area of residence and exposure to pollutants. Environ. Health Persp. 114, 887892.

Wilhelm, M., Ewers, U., Schulz, C., 2003. Revised and new reference values for some persistent organic pollutants (POPs) in blood for human biomonitoring in environmental medicine. Int. J. Hyg. Environ. Health 206, 223-229.

Wilhelm, M., Schulz, C., Schwenk, M., 2006. Revised and new reference values for arsenic, cadmium, lead and mercury in blood and urine of children: basis for validation of human biomonitoring data in environmental medicine. Int. J. Hyg. Environ. Health 209, 301-305.

Wittman, R., Howard, H., 2002. Cadmium exposure and nephropathy in a 28-year-old female metals worker. Environ. Health Persp. 110, 12611266. 